\title{
PENGEMBANGAN DESAIN PEMBELAJARAN MATEMATIKA BERBANTUAN APLIKASI GEOENZO UNTUK MENUMBUHKAN KEMAMPUAN METAKOGNITIF SISWA SMK MEGA LINK MAJENE
}

\author{
Syamsuddin', Herlina Ahmad ${ }^{2 *}$ \\ IUniversitas Terbuka, ${ }^{2}$ Universitas Al Asyariah Mandar \\ "Email: herlinaahmad39@gmail.com
}

\begin{abstract}
Covid-19 is affecting the world of education. Teachers are intended to change the paradigm of teaching methods, teachers face digital habits. The application of learning applications is an option in instilling mathematical concepts. The application of learning mathematics is one of the media that can be used by teachers in growing students' metacognitive abilities in understanding and solving mathematical problems. This type of research is a design research using the Plomp model with five stages, including: (1) initial assessment stage (2) design stage, (3) realization/construction stage, (4) test, evaluation and revision stage, and (5) stage implementation. This study aims to design three-dimensional learning assisted by the GeoEnzo application to foster students' metacognitive abilities in understanding and solving mathematical problems, especially three-dimensional material. The subjects of this study were students of class XII SMK Mega Link Majene which opened 40 people. This research resulted in: (1) the development of mathematical learning tools, especially on threedimensional material that was valid, practical, and effective; (2) student activity observation sheets and teacher implementation; (3) student response questionnaires; and (4) learning outcomes test. The results of the research on the development of the GeoEnzo-assisted mathematics learning design are valid, practical, and effective for improving the metacognitive abilities of the students of SMK Mega Link Majene.
\end{abstract}

Keywords: metacognition, plomp model, mathematics learning design, GeoEnzo

\section{PENDAHULUAN}

Mendesain pembelajaran matematika merupakan suatu upaya untuk memecahkan masalah kemampuan matematika siswa. Mendesain pembelajaran bertujuan agar proses dan hasil belajar matematika efektif dan efisien (Ahmad \& Dkk, 2020). Olehnya itu dibutuhkan hasil desain pembelajaran matematika yang baik. Hal ini sejalan dengan pendapat Nieveen (Ahmad, 2014) desain pembelajaran dikatakan baik jika memenuhi 3 kriteria yaitu sahih (valid), praktis, dan efektif. 
Plomp merupakan salah satu ahli pengembangan, model pengembangan Plomp terdiri atas 5 tahap (Latif et al., 2019) yaitu tahap pengkajian awal, tahap perancangan, tahap realisasi/konstruksi, tahap tes, evaluasi dan revisi, dan tahap implementasi.

O'neil \& Brown (Murtafiah et al., 2018) mengemukakan pengertian metakognisi merupakan proses seseorang berpikir tentang berpikir mereka sendiri dalam rangka membangun strategi untuk memecahkan masalah. Anderson \& Krathwohl (Ahmad, 2017) merevisi Taksonomi Bloom tentang aspek kognitif menjadi dua dimensi, yaitu: (1) dimensi proses kognitif dan (2) dimensi pengetahuan. Penilaian kemampuan metakognisi yang baik digunakan adalah penialain kinerja, hal ini sejalan dengan hasil penelitian (Ahmad, 2017) yang efektif mengukur kemampuan metakognitif siswa.

Untuk mengembangkan potensi metakognitif siswa, dibutuhkan alat bantu dalam proses pembelajaran di kelas. Alat bantu yang digunakan salah satunya adalah media pembelajaran berbasis aplikasi. Saat ini aplikasi matematika banyak dikembangkan oleh para ahli yang bersifat gratis, salah satunya GeoEnzo.

GeoEnzo dapat menjadi alternative media pembelajaran, khususnya penerapan pada materi geometri (Ahmad et al., 2020). GeoEnzo salah satu media pembelaajran yang tepat digunakan di masa covid-19. GeoEnzo dapat diterapkan baik pembelajaran tatap muka terbatas maupun pembelajaran online, sebab prinsip yang ada pada GeoEnzo yaitu dapat dijadikan sebagai layar pengganti papan tulis. Dalam kaitannya dengan pembelaajran geometri, GeoEnzo relative mudah dikunakan dengan sebuah klik saja GeoEnzo dapat menampilkan geometri baik bangun datar maupun bangun ruang, serta dapat menghadirkan teks, sehingga sangat memudahkan guru matematika dalam mengajar (Ahmad, Syamsuddin dan Hasliana, 2021).

Hasil observasi yang dilakukan di SMK Mega Link Majene diperoleh beberapa hal, diantaranya (1) $95 \%$ siswa menganggap materi dimensi tiga merupakan materi yang sangat sulit, (2) guru belum pernah menggunakan media pembelajaran pada saat menjelaskan materi dimensi tiga. Berdasarkan hal tersebut dan teori yang telah dikemukakan sebelumnya, maka rumusan penelitian ini adalah "bagaimanakah desain pembelajaran matematika berbantuan aplikasi GeoEnzo dalam menumbuhkan kemampuan metakognitif siswa SMK Mega Link Majene?". Tujuan penelitian ini yaitu menghasilkan desain pembelajaran matematika berbantuan aplikasi GeoEnzo untuk menumbuhkan kemampuan metakognitif siswa SMK Mega Link Majene yang berkualitas dengan kriteria valid, praktis dan efektif. 


\section{METODE PENELITIAN}

Jenis penelitian ini adalah penelitian desain dengan model pengembangan Plomp. Pengembangan model Plomp terdiri dari lima tahapan (Latif et al., 2019) yaitu (1) tahap pengkajian awal (Preliminary Investigation Phase). (2) tahap perancangan (design phase). (3) tahap realisasi/konstruksi (realization/construction phase). (4) tahap tes, evaluasi dan revisi (test, evaluation and revision phase) dan (5) tahap implementasi (implementation phase). Berikut adalah gambar 1 bagan alir penelitian.

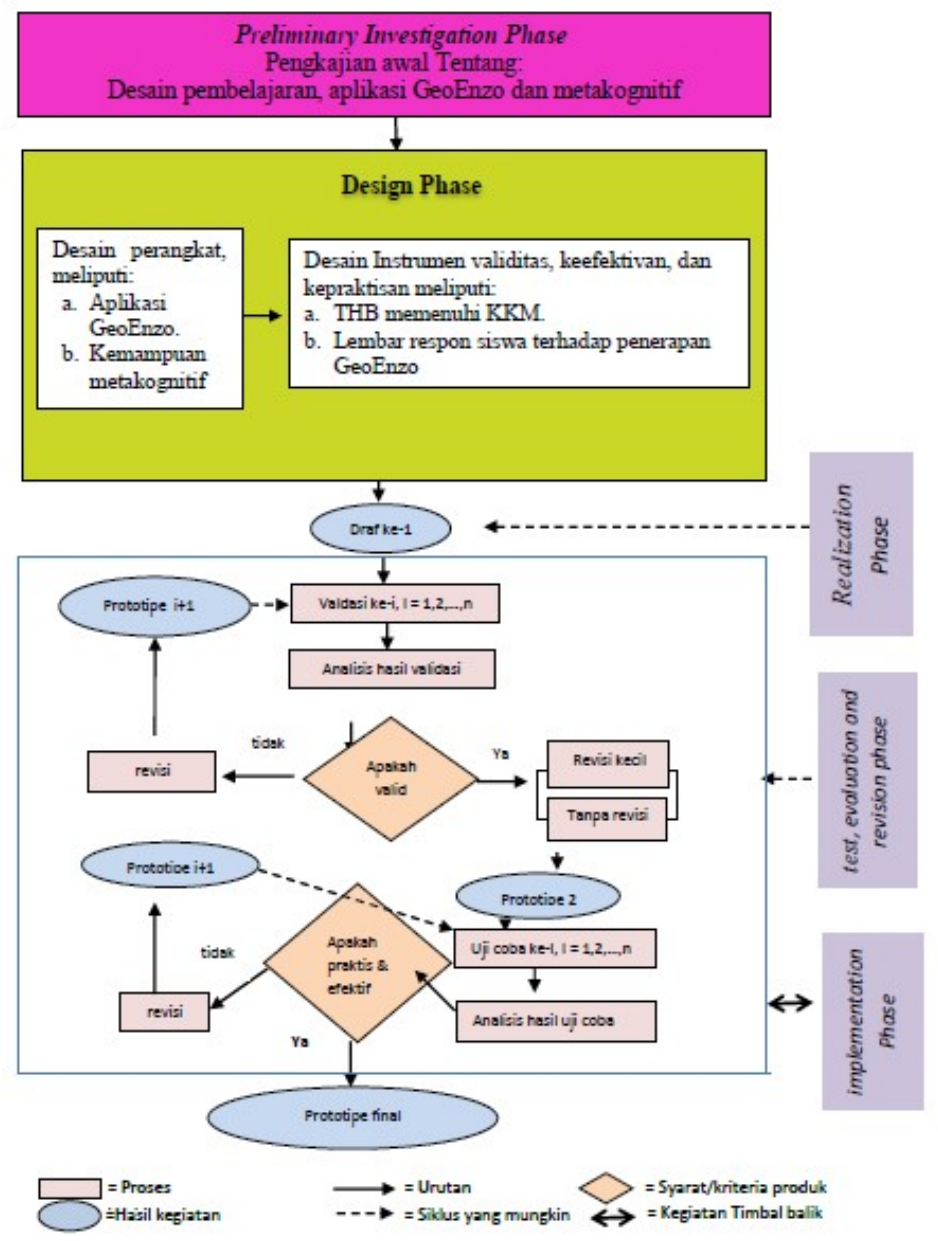

Gambar 1. Bagan alir penelitian. 
Subjek dalam penelitian ini adalah siswa kelas XII Multimedia SMK Mega Link Majene yang berjumlah 40 orang yang terdiri dari 12 laki-laki dan 28 perempuan.

Alat yang digunakan dalam penelitian ini adalah (1) tes kinerja kemampuan metakognitif. (2) lembar pengamatan penerapan aplikasi GeoEnzo pada materi dimensi tiga. (3) lembar pengamatan aktivitas siswa selama penerapan aplikasi GeoEnzo pada materi dimensi tiga. (4) angket respon terhadap proses pembelajaran dan penggunaan aplikasi GeoEnzo.

Data yang dikumpulkan dalam penelitian ini adalah data kuantitatif hasil validasi ahli, kemampuan metakognitif, aktivitas siswa, pengelolaan pembelajaran dan respon siswa. Data kuantitatif berupa tes kemampuan metakognitif dianalisis dengan statistik deskriptif, sedangkan data kualitatif diarahkan untuk menjawab "Bagaimana proses dan hasil pengembangan desain pembelajaran matematika berbantuan aplikasi GeoEnzo untuk menumbuhkan kemampuan metakognitif siswa SMK Mega Link Majene, yaitu memenuhi kriteria kevalidan, kepraktisan dan keefektifan?".

Tahap ke-1: pengkajian awal. Pada tahap ini dilakukan pengkajian awal tentang desain pembelajaran matematika, aplikasi GeoEnzo, kemampuan metakognitif siswa SMK Mega Link Majene, karakteristik materi dimensi tiga.

Tahap ke-2: Perancangan. Pada tahap ini dilakukan perancangan desaian perangkat pembelajaran dan desain instrument validitas, keefektifan dan kepraktisan. Perancangan desain perangkat pembelajaran meliputi aplikasi GeoEnzo, rencana pelaksanaan pembelajaran, lembar kerja peserta didik, bahan ajar untuk memberi stimulasi peningkatan kemampuan metakognitif siswa. Sedangkan desain instrument meliputi tes hasil belajar untuk mengungkap kemampuan metakognitif siswa, lembar pengamatan penerapan aplikasi GeoEnzo pada materi dimensi tiga. lembar pengamatan aktivitas siswa selama penerapan aplikasi GeoEnzo pada materi dimensi tiga. dan angket respon terhadap proses pembelajaran dan penggunaan aplikasi GeoEnzo.

Tahap ke-3: Realisasi/konstruksi. Pada tahap ini dihasilkan draft desain pembelajaran matematika khususnya pada materi dimensi tiga, berbantuan aplikasi GeoEnzo untuk meningkatkan kemampuan metakognitif siswa SMK Mega Link Majene, yang selanjutnya akan divalidasi di tahap tahap tes, evaluasi dan revisi.

Tahap ke-4. Tes, evaluasi dan revisi. Pada tahap ini dilakukan uji validitas. Selanjutnya dilakukan tahap uji coba di tahap implementasi.

Tahap ke-5: Implementasi. Pada tahap ini dilakukan uji coba terhadap desain desain pembelajaran matematika khususnya pada materi dimensi tiga, berbantuan aplikasi GeoEnzo untuk meningkatkan 
kemampuan metakognitif siswa SMK Mega Link Majene, untuk menilai keefektifan dan kepraktisan desain pembelajaran.

Adapun rubrik kinerja dalam memahami dan memecahkan masalah Matematika dibagi atas lima level, diantaranya: (1) level $4=$ superior, (2) level 3 = tinggi, (3) level 2 = sedang, (4) level $1=$ rendah, dan (5) level $0=$ sangat rendah (Arsyad, 2016).

\section{HASIL DAN PEMBAHASAN}

1. Analisis data kevalidan pengembangan desain pembelajaran matematika berbantuan aplikasi GeoEnzo untuk menumbuhkan kemampuan metakognitif siswa SMK Mega Link Majene

Peneliti menyusun prangkat pembelajaran diantaranya (1) lembar kerja peserta didik, (2) bahan ajar dimensi tiga, dan (3) rencana pelaksanaan pembelajaran. Ke tiga perangkat tersebut divalidasi oleh ahli. Hasil analsis validasi oleh ahli diperoleh: lembar kerja peserta didik dinyatakan valid dengan rata-rata 4,00. Bahan ajar dimensi tiga dinyatakan valid dengan rata-rata 3,85. Rencana pelaksanaan pembelajaran dinyatakan valid dengan rata-rata 4,00.

Selain perangkat pembelajaran, instrument penelitian juga divalidasi. Adapaun instrument penelitian yang divalidasi yaitu (1) tes hasil belajar, (2) lembar observasi siswa, (3) lembar observasi pengelolaan guru dalam mengelola pembelajaran, dan (4) angket respon siswa. Hasil analsis validasi oleh ahli diperoleh: tes hasil belajar dinyatakan valid dengan rata-rata 3,75. lembar observasi siswa dinyatakan valid dengan rata-rata 4,00. Lembar observasi keterlaksanaan peneliti dalam menerpakan pembelajaran dinyatakan valid dengan rata-rata 4,00 .

Berdasarkan hasil validitas perangkat pembelaajran dan instrument penelitian, maka disimpulkan pengembangan desain pembelajaran matematika berbantuan aplikasi GeoEnzo untuk menumbuhkan kemampuan metakognitif siswa SMK Mega Link Majene. 
2. Analisis data kepraktisan pengembangan pembelajaran matematika berbantuan aplikasi GeoEnzo untuk menumbuhkan kemampuan metakognitif siswa SMK Mega Link Majene

Tabel 1. Hasil observasi guru

\begin{tabular}{|l|l|l|l|}
\hline \multicolumn{1}{|c|}{ Aspek yang diamati } & $\begin{array}{c}\text { Pertemuan } \\
\text { pertama }\end{array}$ & $\begin{array}{l}\text { Pertemuan } \\
\text { kedua }\end{array}$ & $\begin{array}{c}\text { Pertemuan } \\
\text { ketiga }\end{array}$ \\
\hline $\begin{array}{l}\text { Memastikan protokol kesehatan } \\
\text { dijalankan oleh peserta didik. }\end{array}$ & Terlaksana & Terlaksana & Terlaksana \\
\hline $\begin{array}{l}\text { Menyampaikan tujuan } \\
\text { pembelajaran. }\end{array}$ & Terlaksana & Terlaksana & Terlaksana \\
\hline $\begin{array}{l}\text { Menyampaikan manfaat materi } \\
\text { dimensi tiga dalam kehidupan } \\
\text { sehari-hari representasi geometri } \\
\text { adalah bangunan seperti rumah, } \\
\text { kantor, dll dan terampil } \\
\text { mengoperasikan komputer. }\end{array}$ & Terlaksana & Terlaksana & Terlaksana \\
\hline $\begin{array}{l}\text { Memberi kesempatan kepada } \\
\text { peserta didik untuk bertanya hal } \\
\text { yang belum dimengerti. }\end{array}$ & Terlaksana & Terlaksana & Terlaksana \\
\hline $\begin{array}{l}\text { Membagi dan membimbing } \\
\text { peserta didik yang mengalami } \\
\text { kesulitan dalam mengerjakan } \\
\text { LKPD. Terlaksana }\end{array}$ & Terlaksana & Terlaksana \\
\hline $\begin{array}{l}\text { Memberi kesempatan kepada } \\
\text { beberapa Peserta didik untuk } \\
\text { mempersentasikan terlaksana } \\
\text { pekerjaan LKPD. }\end{array}$ & Terlaksana & Terlaksana \\
\hline $\begin{array}{l}\text { Memberi penguatan terhadap } \\
\text { persentasi peserta didik. }\end{array}$ & Terlaksana & Terlaksana & Terlaksana \\
\hline $\begin{array}{l}\text { Memberi penghargaan kepada } \\
\text { peserta didik yang menjawab } \\
\text { tepat LKPD dan memotivasi } \\
\text { siswa lainnya yang masih } \\
\text { kesulitan mengerjakan LKPD. }\end{array}$ & Terlaksana & Terlaksana & Terlaksana \\
\hline $\begin{array}{l}\text { Bersama-sama siswa } \\
\text { derangkum materi yang telah } \\
\text { dipelajari. Terlaksana }\end{array}$ & Terlaksana & Terlaksana \\
\hline Menutup pembelajaran, dengan & Terlaksana & Terlaksana & Terlaksana \\
\hline
\end{tabular}


momotivasi siswa untuk terus belajar, menjaga kesehatan dan mematuhi protokol kesehatan serta mengucapkan salam. DOI: $10.35329 /$ fkip.v17i2.2683

Berdasarkan tabel 1 disimpulkan bahwa $100 \%$ guru mengelola pembelajaran dengan sangat tinggi, hal ini dilihat dari terlaksananya setiap aspek pengamatan dari pertemuan pertama, pertemuan kedua dan pertemuan terakhir yaitu pertemuan ketiga. Hal ini menunjukkan kepraktisan pengembangan pembelajaran matematika berbantuan aplikasi GeoEnzo untuk menumbuhkan kemampuan metakognitif siswa SMK Mega Link Majene.

3. Analisis data keefektifan pengembangan pembelajaran Matematika berbantuan aplikasi GeoEnzo untuk menumbuhkan kemampuan metakognitif siswa SMK Mega Link Majene

Analisis kemampuan metakognitif siswa, disajikan pada tabel 2 berikut.

Tabel 2. Analsis kemampuan metakognitif

\begin{tabular}{lll}
\hline Indikator & Nilai & Kriteria \\
\hline $\begin{array}{l}\text { Siswa dapat menyoroti rumus-rumus penting dari materi } \\
\text { tiga dimensi. }\end{array}$ & 3,29 & Tinggi \\
$\begin{array}{l}\text { Siswa dapat membuat catatan pinggir tentang konsep dan } \\
\text { prinsip dalam materi tiga dimensi. }\end{array}$ & 3,23 & Tinggi \\
$\begin{array}{l}\text { Siswa dapat membuat ringkasan materi tiga dimensi. } \\
\text { Siswa dapat membuat pemetaan konsep dari materi tiga } \\
\text { dimensi. }\end{array}$ & 3,20 & Tinggi \\
\hline Nilai rata-rata & & Tinggi \\
\hline
\end{tabular}

Berdasarkan tabel 2, diperoleh kesimpulan siswa SMK Mega Link Majene berada pada kriteria tinggi dalam hal kemampuan metakognitif pada unsur pemahaman materi dimensi tiga, penilaian ini diperoleh dari hasil analsiis siswa mengerjakan lembar kerja peserta didik. Sedangkan analisis tes hasil belajar siswa, disajikan dalam tabel 3 berikut.

Tabel 3. Analisis tes hasil belajar siswa

\begin{tabular}{ll}
\hline Statistik & Nilai \\
\hline Mean & 85.25 \\
Mode & 83 \\
Standard deviation & 9.89 \\
Variants & 97.88 \\
Maximum value & 97 \\
Minimum value & 56 \\
Persentase ketuntasan & $86 \%$
\end{tabular}


Berdasarkan tabel 2 dan 3 dapat disimpulkan kemampuan metakognitif siswa berada pada kategori tinggi setelah pembelajaran matematika berbantuan aplikasi GeoEnzo, temuan ini sejalan dengan penelitian sebelumnya yang dilakukan oleh Ku dan Ho (2010), Mauladaniyati dan Kurniawan (2018) Novianti (2020) yang menyatakan bahwa pembelajaran matematika menggunakan aplikasi berpotensi meningkatkan kemampuan metakognitif siswa.

Data respon siswa terhadap pembelajaran matematika berbantuan aplikasi GeoEnzo berada pada kategori sangat positif yaitu sebesar $85,25 \%$. Data aktivitas siswa disajikan pada tabel 4 .

Tabel 4. Analsisi aktivitas siswa

\begin{tabular}{|c|c|c|c|c|c|c|}
\hline \multirow[t]{2}{*}{ Aspek yang diamati } & \multicolumn{2}{|c|}{$\begin{array}{c}\text { Pertemuan } \\
\text { pertama }\end{array}$} & \multicolumn{2}{|c|}{$\begin{array}{c}\text { Perteuan } \\
\text { ke-dua }\end{array}$} & \multicolumn{2}{|c|}{$\begin{array}{l}\text { Pertemuan } \\
\quad \text { ke-3 }\end{array}$} \\
\hline & $\mathrm{F}$ & $\%$ & $\mathrm{~F}$ & $\%$ & $\mathrm{~F}$ & $\%$ \\
\hline Siswa memakai masker. & 18 & $86 \%$ & 19 & $90 \%$ & 21 & $100 \%$ \\
\hline $\begin{array}{l}\text { Siswa yang hadir pada saat } \\
\text { pembelajaran. }\end{array}$ & 18 & $86 \%$ & 19 & $90 \%$ & 21 & $100 \%$ \\
\hline $\begin{array}{l}\text { Siswa yang gaduh dan sering } \\
\text { mengganggu temannya. }\end{array}$ & 4 & $19 \%$ & 2 & $10 \%$ & 0 & $0 \%$ \\
\hline $\begin{array}{l}\text { Siswa yang aktif mengerjakan } \\
\text { lembar kerja peserta didik. }\end{array}$ & 18 & $86 \%$ & 19 & $90 \%$ & 21 & $100 \%$ \\
\hline $\begin{array}{l}\text { Siswa yang bertanya saat } \\
\text { menggunakan aplikasi GeoEnzo. }\end{array}$ & 11 & $52 \%$ & 9 & $43 \%$ & 8 & $38 \%$ \\
\hline Siswa aktif menjawab. & 7 & $33 \%$ & 8 & $38 \%$ & 13 & $62 \%$ \\
\hline
\end{tabular}

Berdasarkan tabel 4 disimpulkan aktivitas siswa yang positif berada pada kategori sangat aktif, sedangkan aktivitas siswa yang negative berada pada kategori kurang.

Berdasarkan kriteria keefektifan pengembangan pembelajaran Matematika berbantuan aplikasi GeoEnzo untuk menumbuhkan kemampuan metakognitif siswa SMK Mega Link Majene yaitu tes hasil belajar, respon siswa dan aktivitas siswa, ketiganya memenuhi kriteria efektif. Oleh sebab itu dapat diartikan pengembangan pembelajaran Matematika berbantuan aplikasi GeoEnzo efektif untuk menumbuhkan kemampuan metakognitif siswa SMK Mega Link Majene.

\section{SIMPULAN}

Rata-rata validitas perangkat dan instrument berada pada kategori valid, kepraktisan pengelolaan guru dalam mengelola pembelajaran berada pada kategori sangat tinggi, dan efektifitas hasil tes hasil belajar, angket respon siswa 
dan aktivitas siswa memenuhi kriteria. Berdasarkan hal tersbut, dapat disimpulkan bahwa pengembangan desain pembelajaran matematika berbantuan GeoEnzo valid, praktis, dan efektif untuk menumbuhkan kemampuan metakognitif siswa SMK Mega Link Majene.

\section{SARAN DAN REKOMENDASI}

Peneliti lainnya dapat menggunakan aplikasi GeoEnzo pada materi lainnya, karena penelitian ini hanya di fokuskan pada materi dimensi tiga.

\section{DAFTAR PUSTAKA}

Ahmad, \& Dkk. (2020). Uji Validitas Desain Pembelajaran Trigonometri. Prosiding Seminar Nasional Integrasi Matematika Dan Nilai Islami, 3(1), 384-395.

Ahmad, H. (2014). Desain Pembelajaran Matematika yang Memanfaatkan Model Kooperatif dengan Pendekatan Kontekstual pada Kelas XA SMK Bina Generasi Polewali. Jurnal Pepatuzdu, 7(1), 39-55.

Ahmad, H. (2017). Application of Teaching Model of Developing Metacognitive Ability ( DMA ) In Teaching Mathematics. Prosiding SI MaNIs, 1(1), $403-413$.

Ahmad, H., Hasliana, L., Latif, A., \& Tasni, N. (2020). Jurnal Cemerlang: Pengabdian Pada Masyarakat Pkm - Peningkatan Keterampilan Guru Matematika Smk Kabupaten Majene Dalam Penggunaan Geoenzo Sebagai Media Pembelajaran Matematika Jurnal Cemerlang: Pengabdian pada Masyarakat Guru Matematika SMK Kabupaten Ma. 3(1), 60-73.

Ahmad, H. (2017). Application of Teaching Model of Developing Metacognitive Ability ( DMA ) In Teaching Mathematics. Prosiding SI MaNIs, 1(1), 403-413.

Ahmad, Syamsuddin dan Hasliana. 2021. Aplikasi GeoEnzo sebagai Media Pembelajaran Matematika. Yogyakarta: KBM Indonesia.

Ku, K. Y. L., \& Ho, I. T. (2010). Metacognitive strategies that enhance critical thinking. Metacognition and Learning. https://doi.org/10.1007/s11409-0109060-6

Latif, A., Yakin, A. Al, \& Ahmad, H. (2019). Digital classroom untuk meningkatkan kemampuan metakognisi. Journal LL_DIKTI IX, I(1), $71-79$.

Murtafiah, Masrura, S. I., Indrawati, N., Arsyad, N., \& Awi. (2018). The Development of Learning Package Based on Metacognitive Strategies to Build the Students Character. Journal of Physics: Conference Series, 1028(1). https://doi.org/10.1088/1742-6596/1028/1/012127

Arsyad, N. (2016). Model Pembelajaran Menumbuhkembangkan Kemampuan Metakognitif. Makassar: Pustaka Refleksi. 
Ku, K. Y. L., \& Ho, I. T. (2010). Metacognitive strategies that enhance critical thinking. Metacognition and Learning. https://doi.org/10.1007/s11409-0109060-6

Latif, A., Yakin, A. Al, \& Ahmad, H. (2019). Digital classroom untuk meningkatkan kemampuan metakognisi. Journal LL_DIKTI IX, 1(1), 71-79.

Mauladaniyati, R. and Kurniawan, D. "GeoEnzo utilization as mathematics learning media with contextual approach to increase geometry understanding," 2018, doi: 10.1088/1742-6596/1132/1/012035.

Murtafiah, Masrura, S. I., Indrawati, N., Arsyad, N., \& Awi. (2018). The Development of Learning Package Based on Metacognitive Strategies to Build the Students Character. Journal of Physics: Conference Series, 1028(1). https://doi.org/10.1088/1742-6596/1028/1/012127.

Novianti, I. "Using GeoEnZo software in geometry to teach Primary School Teacher (PST) students," in Emerging Perspectives and Trends in Innovative Technology for Quality Education 4.0, 2020. 